\title{
Accumulation of Metals in Juvenile Carp (Cyprinus carpio) Exposed to Sublethal Levels of Iron and Manganese: Survival, Body Weight and Tissue
}

\author{
Sándor Harangi ${ }^{1} \cdot$ Edina Baranyai $^{2} \cdot$ Milán Fehér $^{3} \cdot$ Csilla Noémi Tóth $^{2} \cdot$ \\ Petra Herman $^{2}$ - László Stündl ${ }^{3}$ - István Fábián ${ }^{2}$ • Béla Tóthmérész ${ }^{4}$ - Edina Simon ${ }^{1}$
}

Received: 30 May 2016 / Accepted: 13 September 2016

(C) Springer Science+Business Media New York 2016

\begin{abstract}
Many oxbows are contaminated by $\mathrm{Fe}$ and $\mathrm{Mn}$ as a consequence of the elemental concentration of sediment and water originating from the Upper Tisza Region of Hungary. The phenomenon is partly caused by anthropogenic activities and mainly due to the geochemical characteristics of the region. The effects of $\mathrm{Fe}$ and $\mathrm{Mn}$ on the aquatic ecosystem of these wetlands were investigated in a model experiments in this study. Survival, individual body weight and the elemental concentrations of organs were determined in common carp (Cyprinus carpio) juveniles reared in $\mathrm{Fe}$ and $\mathrm{Mn}$ contaminated media (treatment 1: Fe $0.57 \mathrm{mg} \mathrm{L}^{-1}$, Mn $0.29 \mathrm{mg} \mathrm{L}^{-1}$, treatment 2: Fe $0.57 \mathrm{mg} \mathrm{L}^{-1}$, Mn $0.625 \mathrm{mg} \mathrm{L}^{-1}$, treatment 3: Fe $1.50 \mathrm{mg} \mathrm{L}^{-1}$, Mn $0.29 \mathrm{mg} \mathrm{L}^{-1}$, treatment 4: Fe $1.50 \mathrm{mg} \mathrm{L}^{-1}$, Mn $0.625 \mathrm{mg} \mathrm{L}^{-1}$ and control: Fe $0.005 \mathrm{mg} \mathrm{L}^{-1}$, Mn $0.003 \mathrm{mg} \mathrm{L}^{-1}$ ), for rearing time of 49 days. The treatment with $\mathrm{Fe}$ and $\mathrm{Mn}$ did not have any effect on the survival data and individual body weight in the levels tested. The highest concentration of $\mathrm{Fe}$ and $\mathrm{Mn}$ was found in the liver and brain of carp juveniles, while the lowest concentration of these elements occurred in the muscular tissue and gills. The treatment where Fe and Mn were applied in the highest concentrations resulted in a statistically higher level of these elements in the
\end{abstract}

Edina Simon

edina.simon@gmail.com

1 Department of Ecology, University of Debrecen, Debrecen H-4010, Hungary

2 Department of Inorganic and Analytical Chemistry, Agilent Atomic Spectroscopy Partner Laboratory, University of Debrecen, Debrecen H-4010, Hungary

3 Faculty of the Agricultural and Food Sciences and Environmental Management, University of Debrecen, Debrecen H-4032, Hungary

4 MTA-DE Biodiversity and Ecosystem Services Research Group, Debrecen H-4032, Hungary brain, grills and muscle tissues. The treatment where only $\mathrm{Mn}$ was present in the highest concentration caused increased level of Mn only in the liver. We found metal accumulation in almost every organ; however, the applied concentrations and exposure time did not affect the survival and average body weight of carp juveniles.

Keywords Cyprinus carpio · Organs $\cdot$ Iron · Manganese · Accumulation $\cdot$ MP-AES

\section{Introduction}

The pollution of aquatic ecosystems is a serious problem around the world, especially the heavy metal contamination. The appearance of these elements in water ecosystems is due to two reasons: the natural geological background and the anthropogenic activities, such as industrial and agricultural emission and atmospheric deposition. Metals are deposited in water over time and may be accumulated by aquatic plants and organisms resulting these elements to be present in the whole aquatic ecosystem via food chain [1-3].

Heavy metal pollution reached River Tisza (Hungary) in January 2000, when a large amount of cyanide as well as silver, copper, zinc and cadmium contamination arrived through River Szamos from Romania. The pollution appeared in oxbows near the river and its effects are detected even nowadays in the sediments [4, 5]. Besides the anthropogenic pollution, recent studies have demonstrated that oxbows are highly contaminated by $\mathrm{Fe}$ and $\mathrm{Mn}$ due to the high elemental concentration of sediment and water in the Upper Tisza region of Hungary which originates from the geochemical background [6]. The average $\mathrm{Fe}$ concentration of water was $1.1 \mathrm{mg} \mathrm{L}^{-1}$ while the $\mathrm{Mn}$ concentration appeared to be $0.4 \mathrm{mg} \mathrm{L}^{-1}$ in the oxbows [7]. 
Among vertebrates, fish, frogs and toads are excellent indicators of heavy metal pollution [8-11]. Fish, as indicator organisms, are well suited for the monitoring of polluted aquatic ecosystems, since they are able to accumulate all the harmful substances from water and sediment as well as from the food chain [12-14]. Common carp (Cyprinus carpio L., 1758) is a world-wide freshwater fish species with relatively wide tolerance toward contamination and it is one of the most important farmed fish in Eastern Europe [15]. It is also the most frequent fish in Hungary, which can be found in almost all wetlands and it is an extensively studied species. With respect to meat production, the growth parameters of common carp are well-documented [16-19]. Wong et al. (1982) studied the effect of animal manure and sewage sludge on the mortality and fish meat of common carp demonstrate that the species is a good indicator in toxicity tests [20]. Earlier studies demonstrated the nutritional effects on fatty acid composition and the toxicity of carbamate pesticides in carp, respectively $[21,22]$. The feeding behaviour of carp is omnivorous and it is also a known bioturbator. Consequently, it is an ideal indicator organism due to its contact with the dissolved pollutants in water and with the resuspended surface sediment where the organic and inorganic pollutants can accumulate at a higher level. Furthermore, it also feeds upon plants and species from lower taxonomy aquatic class [21-23].

Has-Schön et al. (2015) investigated the distribution and age-related bioaccumulation of heavy metals such as lead, mercury, cadmium and arsenic in tissues of common carp in one reservoir. They found that the heavy metal adsorption in carp tissue depends such factor as age and body mass [24]. In a model experiment, Garcia-Medina et al. (2013) demonstrated the effect of aluminium on carp blood indicating the possible cytotoxicity and genotoxicity of aluminium for erythrocytes [25]. Varanka et al. (2001) studied the effect of copper sulphate and tannic acid on carp liver biochemistry and morphological parameters. They concluded that toxic effect of copper sulphate and tannic acid may be remarkable in a polluted area than uncontaminated area [26]. Cossarini-Dunier et al. (1988) studied the immune response of $\mathrm{Mn}$ ions on carp. The contaminated model medium $\left(50 \mathrm{mg} \mathrm{L}^{-1}\right.$ $\mathrm{Mn}$ ) did not cause decrease in the antibody production but it had a negative effect on the hematocrit [27].

In this paper, the effects of high $\mathrm{Fe}$ and Mn concentration are investigated on the mortality, individual body weight and the elemental distribution of different organs of common carp in detail. The absorption of both essential and toxic trace metals in biological systems can be affected by interrelations in their metabolic functions. Several studies demonstrate that this phenomenon is present in fish; however, the diversity of its manifestation varies among species and depends on such factors as age, size (both weight and length), feeding habit and ecological requirements [28]. A previous experiment of Fehér et al. (2013) revealed the interactive effect of cobalt treated water on the manganese and zinc adsorption of Lates calcarifer [12]. According to the literature data, it has also found that heavy metal accumulation in tissues of fish species show a certain tendency; however, the reasons and explanations are not yet clearly stated. The different trace metal retentions of tissues may be caused by fish species, the form of the metals available in diet or water, exposure regime or water parameters. Thus, the aim of this study is to measure the accumulation of $\mathrm{Fe}$ and $\mathrm{Mn}$ in carp juveniles and also to assess if the applied treatments affect the level of other elements in carp organs.

\section{Material and Methods}

\section{Experimental Design}

Duration of the experiments were 49 days; there were four treatments and one control in three replicates. In each treatment, 54 common carp (Cyprinus carpio) juveniles were used (18/aquaria). Size homogeneity of the juveniles was tested by measuring the starting body weight of the individuals and evaluating the data by ANOVA test ( $p=0.989$, $F=0.073$ ). The experimental design was set in randomly arranged glass aquaria of $40 \mathrm{~L}$. The following treatments were used: in the treatment 1 , the concentration of Fe was $0.57 \mathrm{mg} \mathrm{L}^{-1}$ and the concentration of Mn was $0.29 \mathrm{mg} \mathrm{L}^{-1}$; in the treatment 2 , the Fe concentration was $0.57 \mathrm{mg} \mathrm{L}^{-1}$ and the $\mathrm{Mn}$ concentration was $0.625 \mathrm{mg} \mathrm{L}^{-1}$; in the treatment 3, the Fe concentration was $1.50 \mathrm{mg} \mathrm{L}^{-1}$ and the $\mathrm{Mn}$ concentration was $0.29 \mathrm{mg} \mathrm{L}^{-1}$; in the treatment 4 , the concentration of $\mathrm{Fe}$ was $1.50 \mathrm{mg} \mathrm{L}^{-1}$ and the concentration of Mn was $0.625 \mathrm{mg} \mathrm{L}^{-1}$. Solid manganese chloride and iron chloride $\left(\mathrm{MnCl}_{2}, \mathrm{FeCl}_{3}\right.$ AnalaR NORMAPUR, VWR) were used to make the solutions with which the desired concentrations in the model mediums were adjusted. Control aquaria were filled up with tap water, which contained $0.006 \mathrm{mg} \mathrm{L}^{-1} \mathrm{Cu}, 0.005 \mathrm{mg} \mathrm{L}^{-1} \mathrm{Fe}$, $2.80 \mathrm{mg} \mathrm{L}^{-1} \mathrm{~K}, 16.19 \mathrm{mg} \mathrm{L}^{-1} \mathrm{Mg}, 0.003 \mathrm{mg} \mathrm{L}^{-1} \mathrm{Mn}$, $31.72 \mathrm{mg} \mathrm{L}^{-1} \mathrm{Na}, 0.36 \mathrm{mg} \mathrm{L}^{-1} \mathrm{Sr}$ and $0.048 \mathrm{mg} \mathrm{L}^{-1} \mathrm{Zn}$. Twelve hours of light/dark periods were applied. Fish were fed with dried feed (ALLER FUTURA $1.5 \mathrm{~mm}$ ) once a day (Table 1). The oxygen saturation was maintained at $100 \%$ by aeration stones and temperature was controlled at $23.0 \pm 0.5{ }^{\circ} \mathrm{C}$. The conductivity of water was $547 \mu \mathrm{S} \mathrm{cm}^{-1}$ and the $\mathrm{pH}$ was 8.0 during the experiments. A $30 \%$ of water exchange was applied in each aquaria every week. The level of Fe and Mn of the water was also monitored weekly to determine the decrease in the 
Table 1 The

composition of the fish food

\begin{tabular}{lc}
\hline Ingredients $(\%)$ & \\
\hline Crude protein & 56 \\
Crude fat & 18 \\
Dry matter content & $91.4 \pm 0.1$ \\
Elemental composition $\left(\mathrm{mg} \mathrm{kg}^{-1}\right)$ \\
$\mathrm{Cu}$ & $16.3 \pm 0.5$ \\
$\mathrm{Fe}$ & $470.4 \pm 23.0$ \\
$\mathrm{~K}$ & $631.1 \pm 50.5$ \\
$\mathrm{Mg}$ & $164.7 \pm 16.3$ \\
$\mathrm{Mn}$ & $49.1 \pm 4.3$ \\
$\mathrm{Na}$ & $582.4 \pm 57.6$ \\
$\mathrm{Sr}$ & $122.9 \pm 7.2$ \\
$\mathrm{Zn}$ & $91.0 \pm 4.2$ \\
\hline
\end{tabular}

concentration; based on the gained results, the proper level of these two elements in the treatments was adjusted again to the initial values.

\section{Sample Preparation and Element Analysis}

Fish were counted and their body weight was determined weekly to study the survival rate and individual body weight. To measure the elemental concentration of the liver, eyes, brain, gills and muscular tissue, three juveniles were selected randomly and sacrificed from each aquaria at the end of the experiment. The sacrificed procedure was by physical methods suggested in the AVMA Guidelines on Euthanasia for fish reported by the American Veterinary Medical Association [29]. During the sample preparation, only plastic tools were used to avoid the metal contamination of the samples. Organs were weighted into glass beakers using analytical balance. They were dried at $105{ }^{\circ} \mathrm{C}$ until constant weight.

Samples were digested on an electric hot plate with $4 \mathrm{ml}$ $65 \%(\mathrm{~m} / \mathrm{m})$ nitric acid (reagent grade, Merck) and $1.0 \mathrm{ml}$ $30 \%(\mathrm{~m} / \mathrm{m})$ hydrogen-peroxide (reagent grade, Merck) at $80{ }^{\circ} \mathrm{C}$ for $4 \mathrm{~h}$. After digestion, samples were diluted with $1 \%$ nitric acid (reagent grade, Merck and Milli-Q water) up to a final volume of $10 \mathrm{ml}$. The concentration of $\mathrm{Cu}, \mathrm{Fe}$, $\mathrm{K}, \mathrm{Mg}, \mathrm{Mn}, \mathrm{Na}, \mathrm{Sr}$ and $\mathrm{Zn}$ was determined by a microwave plasma atomic emission spectrometer (Agilent MP - AES 4200) system. Auto sampler (Agilent SPS3), Meinhard type nebulizer and double pass spray chamber were used. We applied a five-point calibration procedure prepared from multi-element standard solution (Merck ICP multielement standard solution IV). Certified reference material was used (ERM-BB422, fish muscle) during the measurement. The recoveries were within of the $10 \%$ of the certified values for the metals. The wavelengths and measuring parameters were chosen based on the suggestions of the instrument's software (MP Expert).

\section{Evaluation of the Data}

SPSS/PC+ software package was used for the statistical analysis. Homogeneity of variance was tested by Levene test. The elemental concentration results were evaluated by canonical discriminant analysis (CDA). The parameters of survival and individual body weight and the elemental concentration of organs and treatments were studied with ANOVA and Kruskal-Wallis test. Bioconcentration factor (BCF) was calculated as a ratio of the $\mathrm{Fe}$ and $\mathrm{Mn}$ found in the fish tissue $\left(C_{\text {tissue }}\right)$, given in milligram per kilogram for dry weight and the $\mathrm{Fe}$ and $\mathrm{Mn}$ concentration applied in the treatments in water $\left(C_{\text {water }}\right)$, given in milligram per litre [30].

$\mathrm{BCF}=C_{\text {tissue }} / C_{\text {water }}$

\section{Results}

\section{Survival Data and Individual Body Weight}

There was no significant difference among the survival data of the treatments at the end of the experiment $(p=0.797$, $F=0.231$ ). In the treatment 1 , we observed $94.4 \pm 5.6 \%$ survival rate and $98.1 \pm 3.2 \%$ was found in the control and the other three treatments. There was no significant difference among treatments based on individual body weight ( $p=0.124, F=2.352$ ) during the time of the experiment (Table 2).

\section{Concentration of Elements in Different Organs}

The elemental concentration results of organs are indicated in Fig. 1 for $\mathrm{Fe}$ and $\mathrm{Mn}$, as well as in Table 3 for the rest of the measured elements. In the case of the brain, the significantly higher $\mathrm{Mn}$ and Fe concentrations were found only in the treatment $4(p<0.05)$. A significantly higher Mn concentration was measured in the liver of carp juveniles originating from the treatment 3 and treatment $4(p<0.05)$. The treatment 4 statistically resulted in the highest measured Mn concentration $(p<0.05)$ of the muscle, gills and brain compared to the other groups. It was also observed that the Fe concentration was significantly higher in gills of the treatment 4 than that of the second one $(p<0.05)$. Furthermore, in the case of muscle, the measured concentration of $\mathrm{Fe}$ was found to be significantly the highest in the treatment 4 compared to the other groups $(p<0.05)$ (Fig. 1). Our results show that the treatment 4 increased the Mn concentration of organs significantly (Kruskal-Wallis test, $p<0.044, H=34.972$ ).

A significantly higher concentration of $\mathrm{Cu}$ was found in the liver and brain than in the muscle and gills. Furthermore, the level of $\mathrm{Cu}$ was significantly higher in the liver than that in the eyes $(p<0.020, H=63.530)$ 
Table 2 Survival rate and individual body weight (mean $\pm \mathrm{SD}, n=54$ )

\begin{tabular}{lrrrrr}
\hline Treatment & \multicolumn{1}{l}{ Control } & \multicolumn{1}{l}{ 1 } & \multicolumn{1}{l}{3} & \multicolumn{1}{c}{4} \\
\hline Survival rate (\%) & $98.1 \pm 3.2^{\mathrm{a}}$ & $94.4 \pm 5.6^{\mathrm{a}}$ & $98.1 \pm 3.2^{\mathrm{a}}$ & $98.1 \pm 3.2^{\mathrm{a}}$ & $98.1 \pm 3.2^{\mathrm{a}}$ \\
Start of experiment $(\mathrm{g})$ & $6.3 \pm 1.4^{\mathrm{a}}$ & $6.4 \pm 1.4^{\mathrm{a}}$ & $6.3 \pm 1.3^{\mathrm{a}}$ & $6.4 \pm 1.3^{\mathrm{a}}$ & $6.4 \pm 1.4^{\mathrm{a}}$ \\
End of experiment $(\mathrm{g})$ & $6.9 \pm 1.6^{\mathrm{a}}$ & $7.4 \pm 1.7^{\mathrm{a}}$ & $7.6 \pm 1.7^{\mathrm{a}}$ & $7.4 \pm 1.4^{\mathrm{a}}$ & $7.7 \pm 1.8^{\mathrm{a}}$ \\
\hline
\end{tabular}

Notations: treatment 1: Fe $0.57 \mathrm{mg} \mathrm{L}^{-1}$, Mn $0.29 \mathrm{mg} \mathrm{L}^{-1}$, treatment 2: $\mathrm{Fe} 0.57 \mathrm{mg} \mathrm{L}^{-1}$, Mn $0.625 \mathrm{mg} \mathrm{L}^{-1}$,

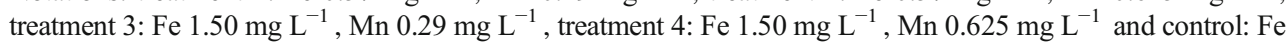
$0.005 \mathrm{mg} \mathrm{L}^{-1}$, Mn $0.003 \mathrm{mg} \mathrm{L}^{-1}$. Different letters indicate significant differences between treatments and the control $(p>0.05)$
(Table 3). The Fe concentration was significantly higher in the liver than that in the other organs and it was significantly higher in the gills and brain than that in the muscle $(p<0.015, H=55.024)$. In the case of $\mathrm{K}$, we found significantly higher concentration in the liver than in the muscle. At the same time, the level of $\mathrm{K}$ was significantly higher in the liver, muscle and in the brain than that in the gills and eyes $(p<0.045, H=64.753)$. The $\mathrm{Mg}$ concentration was significantly higher in the muscle compared to the gills, while the level of $\mathrm{Mg}$ was significantly higher in the muscle, gills and liver than that in the eyes and brain ( $p<0.025, H=64.605)$. Furthermore, the concentration of $\mathrm{Na}$ was significantly higher in the eyes compared to the gills and liver $(p<0.010, H=62.789)$. In the case of $\mathrm{Sr}$, we found significantly higher concentration in the gills than that in the other organs $(p<0.001$, $H=35.453$ ). Higher $\mathrm{Zn}$ level was found in the gills and liver than that in the muscle and brain. The concentration of $\mathrm{Zn}$ was significantly higher in the eyes than that in the muscle $(p<0.001, H=63.463)$. No significant difference occurred in the Mn concentration of the organs $(p>0.05)$.

Using canonical discriminant analysis, the study of elemental concentration of different organs shows that significant differences were found between organs $(p<0.001)$. In the cases of gills and livers, overlap was found (Fig. 2). Effects of treatments show that the elemental concentration of control treatment differed significantly from the treatment 4 using canonical discriminant analysis $(p<0.001)$ (Fig.3). Significant differences were found in the case of concentration of $\mathrm{Mn}$ between treatments.

\section{Bioconcentration of Metals in Common Carp Tissues}

The highest BCF factor for brain and muscle occurred in the treatment 4 , for gills in the treatment 1 and for eyes in the treatment 3, respectively, for Fe and $\mathrm{Mn}$. The only difference between the two applied elements occurred in the case of the liver is as follows: for Fe, the treatment 2 had the highest BCF value while for Mn, the highest factor was calculated in the case of the treatment 3. Detailed results are indicated for $\mathrm{BCF}$ in Table 4.

\section{Discussion}

The applied concentration of Fe and Mn is adjusted based on the measured elemental concentration of oxbows in the Upper Tisza region of Hungary [7]. Based on these data, the Hungarian National Standard (MSZ12749) considers these wetlands toxic to $\mathrm{Fe}\left(>1.0 \mathrm{mg} \mathrm{L}^{-1}\right)$ and $\mathrm{Mn}\left(>0.5 \mathrm{mg} \mathrm{L}^{-1}\right)$. Generally, the concentration of essential trace metals below or over the optimum level in water has negative effects on the fish size, depending on the concentration, species and the chemical elements [31]. Although fish uptake dissolved iron and manganese through the gills, the uptake is more efficient through diet. Watanabe et al. (1997) found that the anaemic is caused by the reduced Fe level in carp but it is not resulted in retard growth parameters [32]. However, the absence of $\mathrm{Mn}$ usually has negative effects on growth. Romanenka (1984) reported better growth performance in the case of carp individuals fed by Mn supplied diet since it increases protein synthesis and decreases fat synthesis in the liver [33]. Ogino and Yang (1980) also reported that lower Mn containing diet resulted in lower growth parameters in carp individuals [34].

Skoric et al. (2012) also studied the elemental concentration of 1- and 2-year-old common carps which were collected from a Serbian fish farm with ponds utilizing water mainly from the Tisza River. They found the following Fe concentration in different organs: in muscle $25 \pm 11 \mathrm{mg} \mathrm{kg}^{-1}$ and in gills $269 \pm 134 \mathrm{mg} \mathrm{kg}^{-1}$ which are similar to our results, but they measured only $103 \pm 37 \mathrm{mg} \mathrm{kg}^{-1} \mathrm{Fe}$ in liver. In the case of $\mathrm{Cu}$ concentration of liver, they had similar result $\left(9.8 \pm 12.6 \mathrm{mg} \mathrm{kg}^{-1}\right)$ to ours. In case of $\mathrm{Mn}$, they measured $2.80 \mathrm{mg} \mathrm{kg}^{-1}$ in liver as well as $2.46 \pm 2.27 \mathrm{mg} \mathrm{kg}^{-1}$ in 1-yearold and $10.6 \pm 3.4 \mathrm{mg} \mathrm{kg}^{-1}$ in 2-year-old common carp gills, which are comparable to our data. In the case of Mn concentration, they reported $925 \pm 45 \mathrm{mg} \mathrm{kg}^{-1}$ in muscle, $486 \pm 36 \mathrm{mg} \mathrm{kg}^{-1}$ in liver and $1086 \pm 203 \mathrm{mg} \mathrm{kg}^{-1}$ in gills, which also show a good concordance to our findings. A lower level of Sr was found in organs, $0.89 \pm 0.39 \mathrm{mg} \mathrm{kg}^{-1}$ in muscle and $0.27 \pm 0.06 \mathrm{mg} \mathrm{kg}^{-1}$ in liver except the gills, where $25.70 \pm 13.62 \mathrm{mg} \mathrm{kg}^{-1}$ was observed compared to our findings. They measured similar concentration of $\mathrm{Zn}$ in muscle $\left(20.51 \pm 4.27 \mathrm{mg} \mathrm{kg}^{-1}\right)$, but their results were an order of magnitude less than in gills $\left(214 \pm 14 \mathrm{mg} \mathrm{kg}^{-1}\right)$ and in liver 
Fig. 1 Concentration of $\mathrm{Fe}$ $($ mean $\pm \mathrm{SE})$ and $\mathrm{Mn}($ mean $\pm \mathrm{SE})$ in the muscle (a), gills (b), liver (c), eye (d) and brain (e). Notations: treatment 1: Fe $0.57 \mathrm{mg} \mathrm{L}^{-1}$, Mn $0.29 \mathrm{mg} \mathrm{L}^{-1}$, treatment 2: Fe $0.57 \mathrm{mg} \mathrm{L}^{-1}$, Mn $0.625 \mathrm{mg} \mathrm{L}^{-1}$, treatment 3: Fe $1.50 \mathrm{mg} \mathrm{L}^{-1}$. Mn $0.29 \mathrm{mg} \mathrm{L}^{-1}$, treatment 4: Fe $1.50 \mathrm{mg} \mathrm{L}^{-1}$, Mn $0.625 \mathrm{mg} \mathrm{L}^{-1}$ and control: $\mathrm{Fe}$ $0.005 \mathrm{mg} \mathrm{L}^{-1}$, Mn $0.003 \mathrm{mg} \mathrm{L}^{-1}$. Different letters indicate significant differences between treatments for the same metal $(p>0.05)$
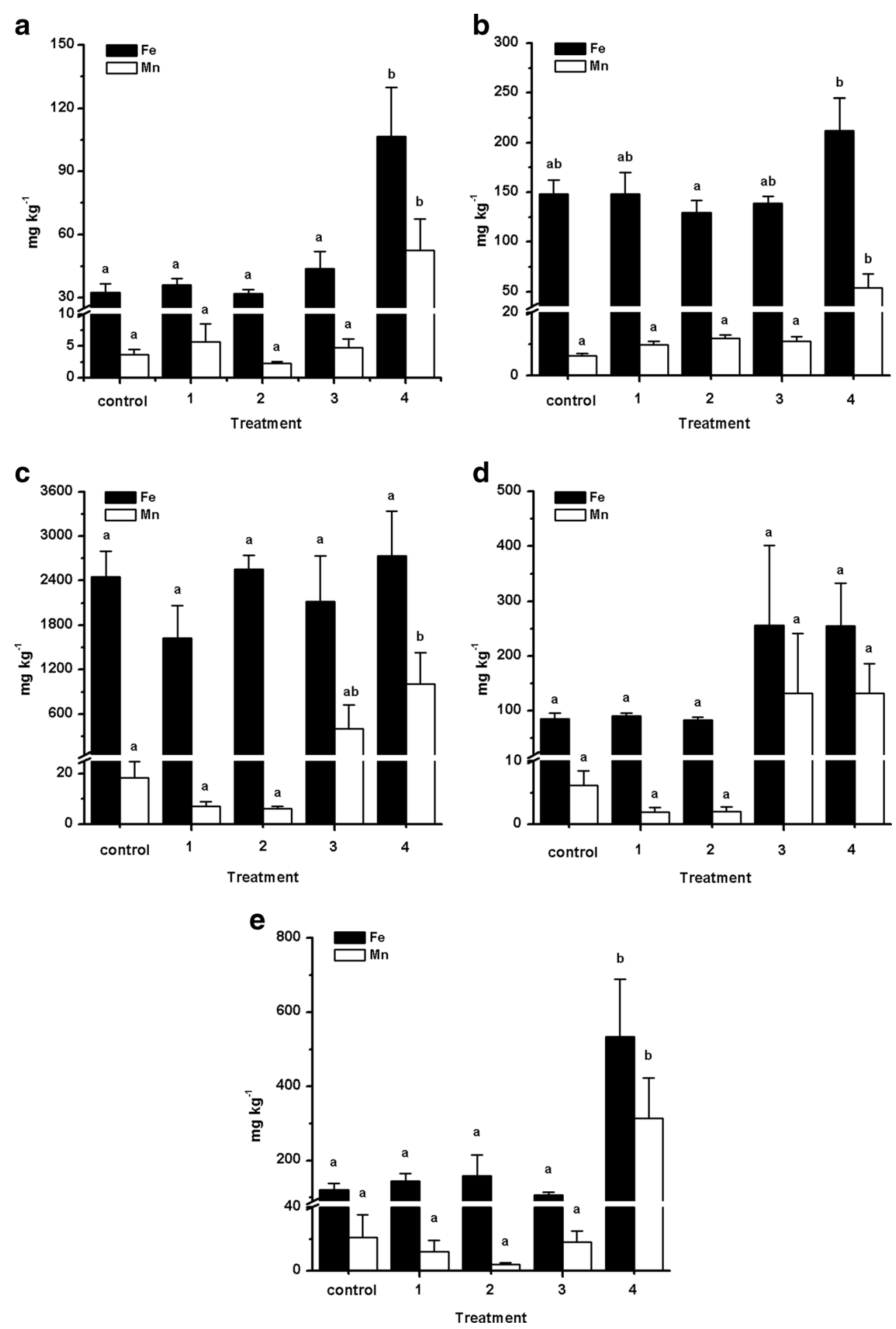

(117 $\pm 38 \mathrm{mg} \mathrm{kg}^{-1}$ ) [35]. Merciai et al. (2014) also examined common carp from a river in the Mediterranean region which was called as Llobregat river; inter alia measured the concentration of $\mathrm{Mn}$ and $\mathrm{Fe}$ in carp muscles. They reported between 2.12 and $15.4 \mathrm{mg} \mathrm{kg}^{-1}$ of $\mathrm{Mn}$ as well as 48.83 and $120.4 \mathrm{mg} \mathrm{kg}^{-1}$ of $\mathrm{Fe}$ [31].

In this study, we observed that the organs are significantly different from each other when their elemental concentrations are considered. Our results demonstrate that the elemental concentration data from the control group did not differ remarkably from treatment 2 and treatment 3 . It indicates that the $\mathrm{Fe}$ and $\mathrm{Mn}$ levels of the treatment 1(0.57 and $0.29 \mathrm{mg} \mathrm{L}^{-1}$, respectively) and treatment $2(0.57$ and $0.625 \mathrm{mg} \mathrm{L}^{-1}$, respectively) did not affect the metabolism of the metals compared to the control; the levels seem to be comparable. In the treatment 3 , however, where $\mathrm{Fe}$ 
Table 3 Elemental concentration ( $\mathrm{mg} \mathrm{kg}^{-1}$, dry weight) of different organs in Cyprinus carpio (mean $\pm \mathrm{SE}, N=3$ )

\begin{tabular}{|c|c|c|c|c|c|c|c|}
\hline Treatment & Organs & $\mathrm{Cu}$ & K & $\mathrm{Mg}$ & $\mathrm{Na}$ & $\mathrm{Sr}$ & $\mathrm{Zn}$ \\
\hline \multirow[t]{5}{*}{ Control } & Muscle & $2.7 \pm 0.2^{\mathrm{a}}$ & $13,451 \pm 836^{\mathrm{b}}$ & $1493 \pm 90^{\mathrm{c}}$ & $1404 \pm 101^{\mathrm{ab}}$ & $9.2 \pm 2.0^{\mathrm{a}}$ & $65 \pm 23^{\mathrm{a}}$ \\
\hline & Gills & $2.6 \pm 0.4^{\mathrm{a}}$ & $7525 \pm 454^{\mathrm{a}}$ & $1022 \pm 68^{b}$ & $4786 \pm 187^{\mathrm{ab}}$ & $64 \pm 6.4^{\mathrm{ab}}$ & $1120 \pm 100^{\mathrm{b}}$ \\
\hline & Liver & $10.4 \pm 2.2^{\mathrm{b}}$ & $22,560 \pm 3603^{c}$ & $1139 \pm 188^{\mathrm{bc}}$ & $4534 \pm 846^{\mathrm{b}}$ & $17 \pm 5.8^{\mathrm{a}}$ & $1572 \pm 357^{\mathrm{b}}$ \\
\hline & Eyes & $4.0 \pm 0.2^{\mathrm{ab}}$ & $7485 \pm 185^{\mathrm{a}}$ & $644 \pm 30^{\mathrm{a}}$ & $11,647 \pm 378^{\mathrm{bc}}$ & $15 \pm 4.4^{\mathrm{a}}$ & $681 \pm 37^{\mathrm{ab}}$ \\
\hline & Brain & $7.4 \pm 0.3^{\mathrm{ab}}$ & $15,198 \pm 143^{b c}$ & $610 \pm 12.4^{\mathrm{a}}$ & $5597 \pm 202^{\mathrm{bc}}$ & $39 \pm 21^{\mathrm{a}}$ & $88 \pm 8.0^{\mathrm{ab}}$ \\
\hline \multirow[t]{5}{*}{1} & Muscle & $2.7 \pm 0.1^{\mathrm{a}}$ & $14,398 \pm 215^{\mathrm{b}}$ & $1613 \pm 21^{\mathrm{c}}$ & $1563 \pm 49^{\mathrm{ab}}$ & $6.7 \pm 1.6^{\mathrm{a}}$ & $47 \pm 3.9^{\mathrm{a}}$ \\
\hline & Gills & $2.3 \pm 0.3^{\mathrm{a}}$ & $6620 \pm 835^{\mathrm{a}}$ & $1042 \pm 48^{\mathrm{b}}$ & $4783 \pm 149^{\mathrm{ab}}$ & $65 \pm 5.3^{\mathrm{ab}}$ & $972 \pm 116^{\mathrm{b}}$ \\
\hline & Liver & $7.7 \pm 1.8^{b}$ & $17,949 \pm 1338^{\mathrm{c}}$ & $914 \pm 67^{\mathrm{bc}}$ & $5086 \pm 399^{\mathrm{b}}$ & $2.4 \pm 0.5^{\mathrm{a}}$ & $2387 \pm 1084^{b}$ \\
\hline & Eyes & $3.9 \pm 0.2^{\mathrm{ab}}$ & $7571 \pm 158^{\mathrm{a}}$ & $653 \pm 22^{\mathrm{a}}$ & $11,621 \pm 351^{\mathrm{bc}}$ & $6.6 \pm 0.4^{\mathrm{a}}$ & $653 \pm 34^{\mathrm{ab}}$ \\
\hline & Brain & $7.5 \pm 0.6^{\mathrm{ab}}$ & $15,868 \pm 238^{\mathrm{bc}}$ & $644 \pm 17^{\mathrm{a}}$ & $6042 \pm 296^{\mathrm{bc}}$ & $9.2 \pm 6.6^{\mathrm{a}}$ & $99 \pm 12.8^{\mathrm{ab}}$ \\
\hline \multirow[t]{5}{*}{2} & Muscle & $2.5 \pm 0.1^{\mathrm{a}}$ & $13,657 \pm 621^{\mathrm{b}}$ & $1512 \pm 66^{\mathrm{c}}$ & $1422 \pm 85^{\mathrm{ab}}$ & $4.2 \pm 1.1^{\mathrm{a}}$ & $39 \pm 6.1^{\mathrm{a}}$ \\
\hline & Gills & $2.8 \pm 0.3^{\mathrm{a}}$ & $7683 \pm 313^{\mathrm{a}}$ & $951 \pm 52^{\mathrm{b}}$ & $4772 \pm 173^{\mathrm{ab}}$ & $57 \pm 4.7^{\mathrm{ab}}$ & $1265 \pm 134^{\mathrm{b}}$ \\
\hline & Liver & $11.7 \pm 2.5^{\mathrm{b}}$ & $24,680 \pm 3501^{\mathrm{c}}$ & $1118 \pm 91^{\mathrm{bc}}$ & $5309 \pm 496^{\mathrm{b}}$ & $4.4 \pm 1.8^{\mathrm{a}}$ & $1377 \pm 391^{\mathrm{b}}$ \\
\hline & Eyes & $4.1 \pm 0.1^{\mathrm{ab}}$ & $7815 \pm 154^{\mathrm{a}}$ & $667 \pm 13.9^{\mathrm{a}}$ & $12,391 \pm 262^{\mathrm{bc}}$ & $6.7 \pm 0.3^{\mathrm{a}}$ & $702 \pm 42^{\mathrm{ab}}$ \\
\hline & Brain & $7.8 \pm 0.7^{\mathrm{ab}}$ & $15,876 \pm 307^{\mathrm{bc}}$ & $617 \pm 14.3^{\mathrm{a}}$ & $5694 \pm 184^{\mathrm{bc}}$ & $2.6 \pm 0.2^{\mathrm{a}}$ & $80 \pm 4.3^{\mathrm{ab}}$ \\
\hline \multirow[t]{5}{*}{3} & Muscle & $2.7 \pm 0.1^{\mathrm{a}}$ & $14,212 \pm 294^{\mathrm{b}}$ & $1639 \pm 17^{\mathrm{c}}$ & $1511 \pm 119^{\mathrm{ab}}$ & $4.7 \pm 0.9^{a}$ & $38 \pm 5.2^{\mathrm{a}}$ \\
\hline & Gills & $3.0 \pm 0.4^{\mathrm{a}}$ & $7859 \pm 376^{\mathrm{a}}$ & $965 \pm 40^{\mathrm{b}}$ & $4972 \pm 215^{\mathrm{ab}}$ & $58 \pm 5.5^{\mathrm{ab}}$ & $1332 \pm 147^{\mathrm{b}}$ \\
\hline & Liver & $11.4 \pm 1.2^{\mathrm{b}}$ & $21,264 \pm 1340^{\mathrm{c}}$ & $1121 \pm 106^{\mathrm{bc}}$ & $5854 \pm 505^{\mathrm{b}}$ & $3.0 \pm 0.9^{\mathrm{a}}$ & $2044 \pm 946^{\mathrm{b}}$ \\
\hline & Eyes & $4.0 \pm 0.1^{\mathrm{ab}}$ & $7594 \pm 162^{\mathrm{a}}$ & $674 \pm 18^{\mathrm{a}}$ & $11,647 \pm 452^{\mathrm{bc}}$ & $7.4 \pm 0.9^{\mathrm{a}}$ & $707 \pm 32^{\mathrm{ab}}$ \\
\hline & Brain & $7.6 \pm 0.4^{\mathrm{ab}}$ & $15,422 \pm 571^{\mathrm{bc}}$ & $591 \pm 23^{\mathrm{a}}$ & $5927 \pm 260^{\mathrm{bc}}$ & $22 \pm 11.9^{\mathrm{a}}$ & $69 \pm 7.5^{\mathrm{ab}}$ \\
\hline \multirow[t]{5}{*}{4} & Muscle & $2.5 \pm 0.1^{\mathrm{a}}$ & $14,390 \pm 298^{b}$ & $1637 \pm 31^{\mathrm{c}}$ & $1320 \pm 74^{\mathrm{ab}}$ & $8.1 \pm 1.4^{\mathrm{a}}$ & $52 \pm 9.1^{\mathrm{a}}$ \\
\hline & Gills & $2.7 \pm 0.4^{\mathrm{a}}$ & $7622 \pm 466^{\mathrm{a}}$ & $1008 \pm 68^{\mathrm{b}}$ & $4657 \pm 130^{\mathrm{ab}}$ & $61.4 \pm 7.0^{\mathrm{ab}}$ & $1306 \pm 141^{\mathrm{b}}$ \\
\hline & Liver & $6.2 \pm 0.7^{b}$ & $15,866 \pm 1107^{\mathrm{c}}$ & $1018 \pm 124^{\mathrm{bc}}$ & $3447 \pm 200^{\mathrm{b}}$ & $22.3 \pm 6.7^{\mathrm{a}}$ & $591 \pm 113^{\mathrm{b}}$ \\
\hline & Eyes & $3.7 \pm 0.1^{\mathrm{ab}}$ & $7108 \pm 165^{\mathrm{a}}$ & $641 \pm 19^{\mathrm{a}}$ & $11,123 \pm 274^{\mathrm{bc}}$ & $11.9 \pm 2.1^{\mathrm{a}}$ & $461 \pm 56^{\mathrm{ab}}$ \\
\hline & Brain & $7.5 \pm 0.3^{\mathrm{ab}}$ & $16,474 \pm 214^{\mathrm{bc}}$ & $722 \pm 29^{\mathrm{a}}$ & $5544 \pm 75^{\mathrm{bc}}$ & $23 \pm 9.4^{\mathrm{a}}$ & $74 \pm 5.9^{\mathrm{ab}}$ \\
\hline
\end{tabular}

Notations: treatment 1: Fe $0.57 \mathrm{mg} \mathrm{L}^{-1}$, Mn $0.29 \mathrm{mg} \mathrm{L}^{-1}$, treatment 2: Fe $0.57 \mathrm{mg} \mathrm{L}^{-1}$, Mn $0.625 \mathrm{mg} \mathrm{L}^{-1}$, treatment 3: Fe 1.50 mg L $\mathrm{m}^{-1}$, Mn $0.29 \mathrm{mg} \mathrm{L}^{-1}$, treatment 4: $\mathrm{Fe} 1.50 \mathrm{mg} \mathrm{L}^{-1}$, Mn $0.625 \mathrm{mg} \mathrm{L}^{-1}$ and control: $\mathrm{Fe} 0.005 \mathrm{mg} \mathrm{L}^{-1}$, Mn $0.003 \mathrm{mg} \mathrm{L}^{-1}$ ). Different letters indicate significant differences between treatments and the control for the same metal $(p>0.05)$

(1.50 $\left.\mathrm{m} \mathrm{L}^{-1}\right)$ was applied in a higher and $\mathrm{Mn}\left(0.29 \mathrm{mg} \mathrm{L}^{-1}\right)$ in a lower concentration, the overlap is not as unambiguous. This phenomenon may suggest that the Fe level determines more the retention process of Mn and the other trace metals-

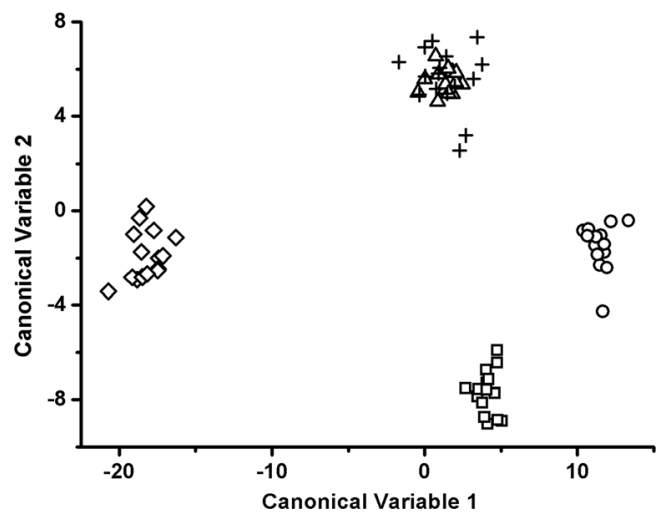

Fig. 2 Scatter plot of canonical discriminant analysis $(C D A)$ based on the elemental concentration of the organs in common carp. Notations: $\square$-brain, ○— eyes, $\triangle$ —iver, —gills, $\diamond$-muscle the higher Fe concentration may caused higher differences between the control and the treatments.

While there is less literature data available for common carp regarding the metal accumulation of organs, the differences found in the present study has been reported for other fish species. Karadede et al. (2004) assessed the heavy metal level in two fish species (Liza abu and Silurus triostegus) collected by fishermen from the Atattürk Dam Lake located on Euphrates. According to their study, the higher heavy metal concentration was found in the liver and gills, while the lowest concentration was observed in muscle, i.e. the different fish tissues show dissimilar affinities for the accumulation of heavy metals. Wei et al. (2014) studied different fish species caught by fishermen in the spring time from lake Poyang, China, and demonstrated that the metals show different affinities to the fish organs since different metabolic ways for heavy metals may be operative in different tissues. Squadrone et al. (2013) draw similar conclusion when European catfish (Silurus glanis) was analysed by electro fishing boat in the Italian rivers covering the Po area [36, 37]. 


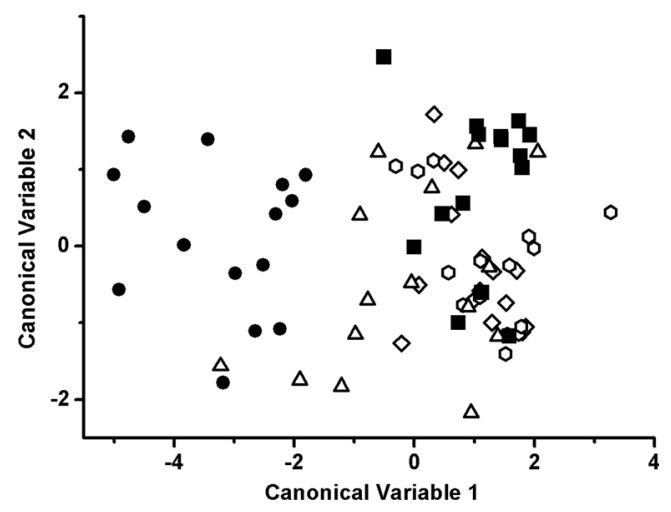

Fig. 3 Scatter plot of canonical discriminant analysis $(C D A)$ based on the elemental concentration of the treatments in common carp. Notations: --control, $\Delta$-treatment 1 , $\triangle$-treatment 2, $\Delta$-treatment 3 , - - treatment 4

Yilmaz et al. (2007) conducted study with Leuciscus cephalus and Lepomis gibbosus from South-West Anatolia showed that the elemental concentration of gills and livers was similar and that the muscle is not an actively accumulating organ. Thus, muscle cannot accumulate metals in high concentration [38]. In contrast to our results, Rajeshkumar et al. (2013) found statistical difference between elemental concentrations of milkfish liver and gill in a polluted area of Kaattuppalli Island, Chennei, India [39].

According to the literature data, the effect of $\mathrm{Fe}$ and $\mathrm{Mn}$ on the biota in the aquatic ecosystem is less studied, while the interactive effect of $\mathrm{Cu}$ and $\mathrm{Zn}$ is much more investigated. Zhao et al. (2011) and Hao et al. (2013) studied the effect of $\mathrm{CuO}$ and $\mathrm{ZnO}$ nanoparticles on the size and weight of juvenile carp organs. We found good agreement with their results in the concentration of $\mathrm{Cu}$ and $\mathrm{Zn}$ of control treatments. According to Zhao et al. (2011), the concentration of $\mathrm{Cu}$ was similar to our findings in the gills, in the liver, in the muscle and in the brain [40]. Hao et al. (2013) also found similar concentrations of $\mathrm{Zn}$ to our results in the gills, liver, muscle and brain [41]. Reynders et al. (2008) studied the metal accumulation in juvenile carp individuals, in Grote Nete River system (Belgium) along a metal pollution gradient. Their results showed a good agreement with ours since they measured $10-15 \mathrm{mg} \mathrm{kg}^{-1} \mathrm{Cu}$ and $1000-2200 \mathrm{mg} \mathrm{kg}^{-1} \mathrm{Zn}$ in carp gills, $10-15 \mathrm{mg} \mathrm{kg}^{-1} \mathrm{Cu}$ and $1500-4000 \mathrm{mg} \mathrm{kg}^{-1} \mathrm{Zn}$ in the liver and $5 \mathrm{mg} \mathrm{kg}^{-1} \mathrm{Cu}$ and $100 \mathrm{mg} \mathrm{kg}^{-1}$ in the carp muscle [42].

Our results for K agree with Partridge and Lymbery (2009) findings since significantly reduced $\mathrm{K}$ concentration was found in the liver of mulloway in fish exposed to Mn [43]. We measured 17-35 times higher $\mathrm{Zn}$ levels in the gills than in the muscle depending on treatments. According to Wei et al. (2014), the concentration of $\mathrm{Zn}$ in the gills of carp was 43 times higher than in the muscle similar to our findings. Furthermore, they demonstrated that the gills and liver can accumulate the greater amounts of heavy metals in benthic fish among organs [37]. This statement is similar to ours since we found that the highest concentration of $\mathrm{Fe}$ and $\mathrm{Zn}$ was in the carp gills and liver. Watanabe (1997) also reported elevated Fe concentration in gills. In our study in the treatment 4 , the highest $\mathrm{Fe}$ and $\mathrm{Mn}$ concentration was found in the gills compared to the control treatment, because the gills may be of direct contact with the water in fish life. The gills are the first organ which is in contact with water and suspended sediment, respectively. One of the possible reasons may be that the slimy region between the gill lamellae partly accumulates trace metals due to the relatively high contact area. Although, these slimy parts are impossible to be removed individually during the sample preparation [32, 38]. Thus, the whole gills were analysed. In spite of the gills and liver are an organ itself for selection tasks thus perfect for controlling the trace metal accumulation.

Bioconcentration factor was used to prove the relation of the concentration of $\mathrm{Fe}$ and $\mathrm{Mn}$ applied in the treatments and measured in fish tissue. It was found in recent study that the rate of
Table 4 Bioconcentration factors $($ mean $\pm \mathrm{SD})$ for $\mathrm{Fe}$ and $\mathrm{Mn}$ in common carp tissues

\begin{tabular}{|c|c|c|c|c|c|c|}
\hline Elements & & $\mathrm{BCF}$ & & & & \\
\hline \multirow[t]{5}{*}{$\mathrm{Fe}$} & Treatments & Muscle & Gills & Liver & Eye & Brain \\
\hline & 1 & $70 \pm 11$ & $259 \pm 105$ & $2858 \pm 998$ & $158 \pm 28$ & $255 \pm 20$ \\
\hline & 2 & $56 \pm 6$ & $227 \pm 67$ & $4486 \pm 453$ & $146 \pm 19$ & $279 \pm 143$ \\
\hline & 3 & $29 \pm 14$ & $93 \pm 4$ & $1412 \pm 715$ & $170 \pm 157$ & $70 \pm 5$ \\
\hline & 4 & $71 \pm 26$ & $141 \pm 39$ & $1825 \pm 799$ & $170 \pm 153$ & $356 \pm 279$ \\
\hline \multicolumn{7}{|l|}{$\mathrm{Mn}$} \\
\hline & 1 & $137 \pm 21$ & $510 \pm 206$ & $5617 \pm 1961$ & $310 \pm 54$ & $502 \pm 40$ \\
\hline & 2 & $51 \pm 5$ & $207 \pm 61$ & $4091 \pm 413$ & $133 \pm 18$ & $254 \pm 130$ \\
\hline & 3 & $152 \pm 70$ & $479 \pm 19$ & $7302 \pm 3687$ & $882 \pm 813$ & $362 \pm 23$ \\
\hline & 4 & $171 \pm 61$ & $339 \pm 95$ & $4380 \pm 1917$ & $408 \pm 367$ & $853 \pm 670$ \\
\hline
\end{tabular}

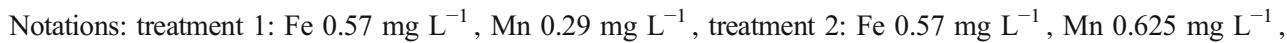

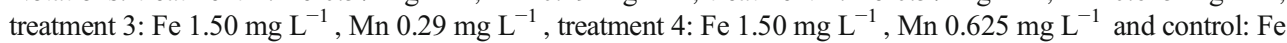
$0.005 \mathrm{mg} \mathrm{L}^{-1}$, Mn $0.003 \mathrm{mg} \mathrm{L}^{-1}$ 
$\mathrm{BCF}$ values shows similarities for $\mathrm{Fe}$ and $\mathrm{Mn}$ in the carp tissues regarding the treatments. With the exception of liver the same rate was observed in all tissues for both the studied metals. In the case of the brain and muscle, the highest bioconcentration was observed in treatment where both $\mathrm{Fe}$ and $\mathrm{Mn}$ were applied in the highest level. In the case of the gills, the $\mathrm{BCF}$ value was found to be the highest in the treatment 1 . This finding correlates with the elemental analysis results; gills showed the least significant difference between the treatments regarding the accumulated level of $\mathrm{Fe}$ and $\mathrm{Mn}$ among the organs. The liver is an important organ in the detoxification pathway of vertebrates. In this study, the highest BCF results were found in all treatments for both $\mathrm{Fe}$ and $\mathrm{Mn}$. Parallel with this finding, the concentration of these two metals occurred to be the highest in the liver of carp juveniles [30].

Subotic et al. (2013) investigated the bioaccumulation of heavy metals and trace elements in target tissues of four edible fish species including common carp originating from the Danube River, Serbia. They found the following bioconcentration factors for common carp: for Fe in the liver, BCF was 126.87, in the muscle, it was 18.31 and in the gills, it was 100.77. The trend of the accumulation was similar in their study for Fe to our results: liver $>$ gills $>$ muscle. According to Subotić et al. (2013) for Mn, the BCF was 37.5 in the liver, 2.2 in the muscle and 137.35 in the gills of carp. The trend in this case slightly differs compared to our data where we found the liver to be the most absorbing organ. In contrast to the study of Subotić et al. (2013), our values for BCF are overall higher since their data apply for freshwater and our BCF results are calculated for an experiment where contaminated model media was used for fish rearing [44].

\section{Conclusions}

During the 49-day exposure period, negative influence of $\mathrm{Fe}$ and $\mathrm{Mn}$ was not detected on the survival and individual body weight of the carp juveniles. The highest concentration of Fe and $\mathrm{Mn}$ was found in the liver and in the brain of the fish, while the lowest concentrations were measured in the muscle tissue and in the gills. The brain, muscle tissue and gills contained statistically higher concentrations of $\mathrm{Fe}$ and $\mathrm{Mn}$ only in the treatment 4 . Iron has a positive effect on the Mn accumulation since in those treatments where the Fe concentration was high, significantly higher concentration of Mn was found. Our results demonstrate that the metal accumulation occur in almost all organs; however, these concentrations and the applied exposure time do not cause notable change either in the survival rate or in the individual body weight of fish. These results therefore suggest that the organs are not affected by the accumulated elements. Furthermore, it was found that the $\mathrm{Fe}$ level determines more the retention process of $\mathrm{Mn}$ and the other trace metals.
Acknowledgments We acknowledge the Agilent Technologies and the Novo-Lab Ltd. (Hungary) for providing the MP-AES 4200. The research was partially supported by the Internal Research Project of the University of Debrecen (E. Simon), by the TÁMOP 4.2.1./B-09/1/KONV-20100024 project and by the SROP-4.2.2.B-15/1/KONV20150001 project.

\section{References}

1. Islam MS, Ahmed MK, Raknuzzaman M et al (2015) Heavy metal pollution in surface water and sediment: a preliminary assessment of an urban river in a developing country. Ecol Indic 48:282-291. doi:10.1016/j.ecolind.2014.08.016

2. Lin H, Sun T, Xue S, Jiang X (2016) Heavy metal spatial variation, bioaccumulation, and risk assessment of Zostera japonica habitat in the Yellow River Estuary, China. Sci Total Environ 541:435-443. doi:10.1016/j.scitotenv.2015.09.050

3. Suárez-Serrano A, Alcaraz C, Ibáñez C et al (2010) Procambarus clarkii as a bioindicator of heavy metal pollution sources in the lower Ebro River and Delta. Ecotoxicol Environ Saf 73:280-286. doi:10.1016/j.ecoenv.2009.11.001

4. Fleit E (2003) Accumulative heavy metal patterns in the sediment and biotic compartments of the Tisza watershed. Toxicol Lett 140 141:323-332. doi:10.1016/S0378-4274(03)00029-8

5. Lakatos G (2003) Ecotoxicological studies and risk assessment on the cyanide contamination in Tisza river. Toxicol Lett 140-141: 333-342. doi:10.1016/S0378-4274(03)00030-4

6. Balogh Z, Harangi S, Kundrát JT et al (2016) Effects of anthropogenic activities on the elemental concentration in surface sediment of oxbows. Water Air Soil Pollut. doi:10.1007/s11270-015-2714-x

7. Kundrát JT, Gyulai I, Baranyai E et al (2014) Felső-Tisza vidéki holtmedrek szennyezettségének felmérése vízminták alapján [Study of contamination of oxbows based on water samples analysis in the Upper-Tisza region]. Hidrol Közl 94:53-55

8. Amundsen P-A, Staldvik FJ, Lukin AA et al (1997) Heavy metal contamination in freshwater fish from the border region between Norway and Russia. Sci Total Environ 201:211-224. doi:10.1016/S0048-9697(97)84058-2

9. Linnik PM, Zubenko IB (2000) Role of bottom sediments in the secondary pollution of aquatic environments by heavy-metal compounds. Lakes Reserv Res Manag 5:11-21. doi:10.1046/j.14401770.2000.00094.x

10. Nimmo DR, Willox MJ, Lafrancois TD et al (1998) Effects of metal mining and milling on boundary waters of Yellowstone National Park, USA. Environ Manag 22:913-926. doi:10.1007/s002679900158

11. Simon E, Braun M, Tóthmérész B (2010) Non-destructive method of frog (Rana esculenta L.) skeleton elemental analysis used during environmental assessment. Water Air Soil Pollut 209:467-471. doi:10.1007/s11270-009-0214-6

12. Fehér M, Baranyai E, Simon E et al (2013) The interactive effect of cobalt enrichment in Artemia on the survival and larval growth of barramundi, Lates calcarifer. Aquaculture 414-415:92-99. doi:10.1016/j.aquaculture.2013.07.031

13. Gupta A, Rai DK, Pandey RS, Sharma B (2009) Analysis of some heavy metals in the riverine water, sediments and fish from river Ganges at Allahabad. Environ Monit Assess 157:449-458. doi:10.1007/s10661-008-0547-4

14. Mendil D, Uluözlü ÖD (2007) Determination of trace metal levels in sediment and five fish species from lakes in Tokat, Turkey. Food Chem 101:739-745. doi:10.1016/j.foodchem.2006.01.050

15. Kestemont P (1995) Different systems of carp production and their impacts on the environment. Aquaculture 129:347-372. doi:10.1016/0044-8486(94)00292-V 
16. Ashouri S, Keyvanshokooh S, Salati AP et al (2015) Effects of different levels of dietary selenium nanoparticles on growth performance, muscle composition, blood biochemical profiles and antioxidant status of common carp (Cyprinus carpio. Aquaculture 446: 25-29. doi:10.1016/j.aquaculture.2015.04.021

17. Kirchgessner M, Schwarz FJ (1986) Mineral content (major and trace elements) of carp (Cyprinus carpio L.) fed with different protein and energy supplies. Aquaculture 54:3-9. doi:10.1016/00448486(86)90248-6

18. Ufodike EBC, Matty AJ (1983) Growth responses and nutrient digestibility in mirror carp (Cyprinus carpio) fed different levels of cassava and rice. Aquaculture 31:41-50. doi:10.1016/00448486(83)90256-9

19. Zhao J, Liu Y, Jiang J et al (2012) Effects of dietary isoleucine on growth, the digestion and absorption capacity and gene expression in hepatopancreas and intestine of juvenile Jian carp (Cyprinus carpio var. Jian. Aquaculture 368-369:117-128. doi:10.1016/j. aquaculture.2012.09.019

20. Wong MH, Cheung YH, Lau WM (1982) Toxic effects of animal manures and sewage sludge as supplementary feeds for the common carp, Cyprinus carpio. Toxicol Lett 12:65-73. doi:10.1016/0378-4274 (82)90200-4

21. Bundschuh M, Schletz M, Goedkoop W (2016) The mode of bioturbation triggers pesticide remobilization from aquatic sediments. Ecotoxicol Environ Saf 130:171-176. doi:10.1016/j. ecoenv.2016.04.013

22. Ritvo G, Kochba M, Avnimelech Y (2004) The effects of common carp bioturbation on fishpond bottom soil. Aquaculture 242:345356. doi:10.1016/j.aquaculture.2004.09.013

23. Zhang X, Liu Z, Jeppesen E et al (2016) Effects of benthic-feeding common carp and filter-feeding silver carp on benthic-pelagic coupling: implications for shallow lake management. Ecol Eng 88: 256-264. doi:10.1016/j.ecoleng.2015.12.039

24. Has-Schön E, Bogut I, Vuković R et al (2015) Distribution and agerelated bioaccumulation of lead $(\mathrm{Pb})$, mercury $(\mathrm{Hg})$, cadmium $(\mathrm{Cd})$, and arsenic (As) in tissues of common carp (Cyprinus carpio) and European catfish (Sylurus glanis) from the Buško Blato reservoir (Bosnia and Herzegovina). Chemosphere 135:289-296. doi:10.1016/j.chemosphere.2015.04.015

25. García-Medina S, Angélica Núñez-Betancourt J, Lucero GarcíaMedina A et al (2013) The relationship of cytotoxic and genotoxic damage with blood aluminum levels and oxidative stress induced by this metal in common carp (Cyprinus carpio) erythrocytes. Ecotoxicol Environ Saf 96:191-197. doi:10.1016/j.ecoenv.2013.06.010

26. Varanka Z, Rojik I, Varanka I et al (2001) Biochemical and morphological changes in carp (Cyprinus carpio L.) liver following exposure to copper sulfate and tannic acid. Comp Biochem Physiol Part C Toxicol Pharmacol 128:467-477. doi:10.1016 /S1532-0456(01)00166-1

27. Cossarini-Dunier M, Demael A, Lepot D, Guerin V (1988) Effect of manganese ions on the immune response of carp (Cyprinus carpio) against Yersinia ruckeri. Dev Comp Immunol 12:573579. doi:10.1016/0145-305X(88)90073-0

28. Mohammadnabizadeh S, Pourkhabbaz A, Afshari R (2014) Analysis and determination of trace metals (nickel, cadmium, chromium, and lead) in tissues of Pampus argenteus and Platycephalus indicus in the Hara Reserve, Iran. J Toxicol 2014:1-6. doi:10.1155/2014/576496
29. Leary SL, American Veterinary Medical Association (2013) AVMA guidelines for the euthanasia of animals: 2013 edition. ISBN 978-1-882691-21-0

30. Voigt CL, da Silva CP, Doria HB et al (2015) Bioconcentration and bioaccumulation of metal in freshwater Neotropical fish Geophagus brasiliensis. Environ Sci Pollut Res 22:8242-8252. doi:10.1007/s11356-014-3967-4

31. Merciai R, Guasch H, Kumar A et al (2014) Trace metal concentration and fish size: variation among fish species in a Mediterranean river. Ecotoxicol Environ Saf 107:154-161. doi:10.1016/j.ecoenv.2014.05.006

32. Watanabe T, Kiron V, Satoh S (1997) Trace minerals in fish nutrition. Aquaculture 151:185-207. doi:10.1016/S0044-8486(96)01503-7

33. Romanenko VD (1984) Metabolic aspects of warmwater culture of the carp, Cyprinus carpio L. Aquaculture 38:307-314. doi:10.1016/00448486(84)90335-1

34. Ogino C, Yang G-Y (1980) Requirements of carp and rainbow trout for dietary manganese and copper. $46455-8$

35. Skoric S, Visnjić-Jeftic Z, Jaric I et al (2012) Accumulation of 20 elements in great cormorant (Phalacrocorax carbo) and its main prey, common carp (Cyprinus carpio) and Prussian carp (Carassius gibelio. Ecotoxicol Environ Saf 80:244-251. doi:10.1016/j. ecoenv.2012.03.004

36. Squadrone S, Prearo M, Brizio P et al (2013) Heavy metals distribution in muscle, liver, kidney and gill of European catfish (Silurus glanis) from Italian rivers. Chemosphere 90:358-365. doi:10.1016 j.chemosphere.2012.07.028

37. Wei Y, Zhang J, Zhang D et al (2014) Metal concentrations in various fish organs of different fish species from Poyang Lake, China. Ecotoxicol Environ Saf 104:182-188. doi:10.1016/j. ecoenv.2014.03.001

38. Yılmaz F, Özdemir N, Demirak A, Tuna AL (2007) Heavy metal levels in two fish species Leuciscus cephalus and Lepomis gibbosus. Food Chem 100:830-835. doi:10.1016/j.foodchem.2005.09.020

39. Rajeshkumar S, Mini J, Munuswamy N (2013) Effects of heavy metals on antioxidants and expression of HSP70 in different tissues of milk fish (Chanos chanos) of Kaattuppalli Island, Chennai, India. Ecotoxicol Environ Saf 98:8-18. doi:10.1016/j. ecoenv.2013.07.029

40. Zhao J, Wang Z, Liu X et al (2011) Distribution of CuO nanoparticles in juvenile carp (Cyprinus carpio) and their potential toxicity. J Hazard Mater 197:304-310. doi:10.1016/j.jhazmat.2011.09.094

41. Hao L, Chen L, Hao J, Zhong N (2013) Bioaccumulation and subacute toxicity of zinc oxide nanoparticles in juvenile carp (Cyprinus carpio): a comparative study with its bulk counterparts. Ecotoxicol Environ Saf 91:52-60. doi:10.1016/j.ecoenv.2013.01.007

42. Reynders H, Bervoets L, Gelders M et al (2008) Accumulation and effects of metals in caged carp and resident roach along a metal pollution gradient. Sci Total Environ 391:82-95. doi:10.1016/j. scitotenv.2007.10.056

43. Partridge GJ, Lymbery AJ (2009) Effects of manganese on juvenile mulloway (Argyrosomus japonicus) cultured in water with varying salinity-implications for inland mariculture. Aquaculture 290: 311-316. doi:10.1016/j.aquaculture.2009.02.020

44. Subotić S, Spasić S, Višnjić-Jeftić Ž et al (2013) Heavy metal and trace element bioaccumulation in target tissues of four edible fish species from the Danube River (Serbia). Ecotoxicol Environ Saf 98: 196-202. doi:10.1016/j.ecoenv.2013.08.020 